\title{
AHAZIAH'S FALL (2 KINGS 1) THE VERSION OF JOSEPHUS
}

CHRISTOPHER BEGG

Catholic University of America. Washington D.C.

2 Kgs 1,2-17a relates king Ahaziah of Israel's - ultimatelyfatal fall '. The purpose of this essay is to examine Josephus' version of the episode in Antiquities IX 19b-27a ${ }^{2}$. More specifically, I intend to compare the Josephan version with the following major ancient witnesses to the biblical text: the Hebrew text $(=\mathrm{MT})^{3}$, the Codex Vaticanus $(=B)^{4}$, the (proto-) Lucianic -or Antiochenerecension $(=\mathrm{L})^{5}$ of the LXX and Targum Jonathan on the Former Prophets $(=\mathrm{TJ})^{6}$. My comparison will address such questions as:

${ }^{1}$ On this text see O. H. STECK, "Die Erzählung von Jahwes Einschreitung gegen die Orakelbefragung Ahasja", EvT 27 (1967) 546-556; A. RofE, "Baal, the Prophet and the Angel (II Kings 1): A Study in the History of Literature and Religion", Beersheva 1 (1973) 221-230 [Hebrew]; C. T. BEGG, "Unifying Factors in 2 Kings 1.217a", JSOT 32 (1985) 75-86; B: O. LONG, 2 Kings, Grand Rapids 1991, pp. 10-18.

${ }^{2}$ I use the text and translation of $\mathrm{H}$. St. J. Thackeray et al. (eds.), Josephus, London - Cambridge, MA 1926-1965. Ant. IX 19-27 is found in vol. VI, pp. 10-16.

${ }^{3}$ For this I use K. Elliger - W. RudolPh (eds.) Biblia hebraica stuttgartensia, Stuttgart 1969-1976.

${ }^{4}$ For this I use the text of A. E. Brooke, N. McLean, and H. ST. J. Thackeray, The Old Testament in Greek II:II, Cambridge 1930. In 4 Reigns 1 B is a representative of the so-called "kaige recension" of the LXX, evidencing a certain assimilation to (proto-) MT. On the point, see J. D. ShEnkel, Chronology and Recensional Development in the Greek Texts of Kings, Cambridge, MA 1968, pp. 10-18.

${ }^{5}$ For L I use the text edited by N. Fernández MArcos and J. R. Busto Saiz, El texto antioqueno de la biblia griega II: 1-2 Reyes, Madrid 1992. In Kings L is represented by the miniscules denoted 19, 108, 82, 93, 127, Z, and 700 by Fernández and Busto. I include this witness in my comparison given the widely-held view that, in the later historical books (i. e. from 1 Samuel on), Josephus is especially dependent on a biblical text-form like that of L. See L. H. Feldman, Josephus and Modern Scholarship (1937-1980), Berlin - New York 1984, pp. 166-170.

${ }^{6}$ I use the edition of A. SPERBER, The Bible in Aramaic, II, Leiden 1959 and the translation of D. J. HARRINGTON and A. J. SALDARINI, Targum Jonathan on the Former Prophets, Wilmington 1987. 
Can anything be determined as to which of the above witnesses Josephus follows in his rewriting of 2 Kings 1 ? What does he omit from, add to, rearrange in, and modify of the biblical account(s)? Finally, what may be the reason for such changes and what are their effects?

To facilitate my comparison between the biblical and Josephan fall stories, I divide up the former into five sections as follows: 1) Ahaziah's fall and inquiry $(1,2) ; 2)$ Elijah's commission $(1,3-4 a) ; 3)$ king-messengers exchange $(1,4 \mathrm{~b}-8)$; 4) Ahaziah's triple mission (1,915a); and 5) Elijah before the king (1,15b-17a). I shall now compare each of these segments with its Josephan pendant in turn.

\section{AHAZIAH'S FALL AND INQUIRY $(1,2)$}

Our episode is set in motion by a fall which Ahaziah suffers in his palace in Samaria, this causing him to become sick (v. la). The Bible specifies that the king "fell through the lattice in his upper chamber" (so RSV). Josephus (IX 19b) gives a somewhat different picture of the royal accident, i. e. Ahaziah "falls down" when "descending from the roof of his house" - the biblical localization of this "in Samaria" is omitted by him. $2 \mathrm{Kgs} 1,2 \mathrm{~b}$ cites, in direct discourse, the commission which the sick Ahaziah entrusts to the messengers dispatched by him: "go inquire ... whether I shall recover from this sickness". Josephus incorporates the words of Ahaziah's commission into the notice on his initiative: "he sent ... to inquire about his chances of recovery". The Bible designates the deity to whom Ahaziah dispatches his messengers as «Baalzebub (BL Bóa $\lambda$ $\mu v i \alpha v)$ the god ' of Ekron". Josephus conflates this double designa-

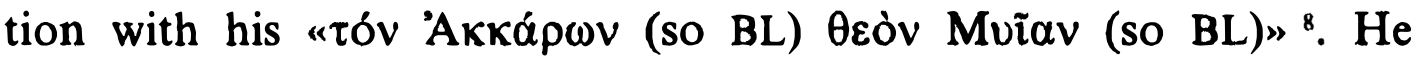
likewise underscores the peculiarity of the divine name in question («Fly-God») with his inserted phrase «this was the god's name».

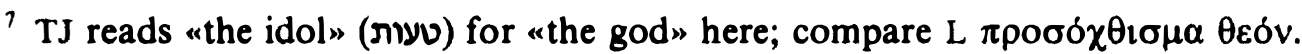

${ }^{8}$ Josephus' avoidance of the proper name Baal here is in line with his practice elsewhere, see e. g., his version of the Carmel contest $(1 \mathrm{Kgs} \mathrm{18,17-40)}$ in Ant. VIII 335-343 where the source's repeated mentions of "Baal(s)" are consistently replaced by "(the) gods". Note that, like MT and B $2 \mathrm{Kgs} 1,2 \mathrm{~b}$, Josephus has no equivalent to the pejorative designation for the Ekron deity found in $\mathrm{L}$ and $\mathrm{TJ}$, see previous note.
} 
ELIJAH'S COMMISSION (1,3-4)

In 1,3 Elijah "the Tishbite" receives his commission from «an

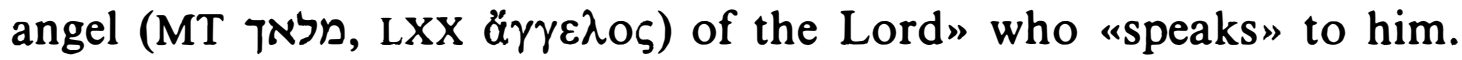
Josephus' designation for Elijah's commissioner differs significantly:

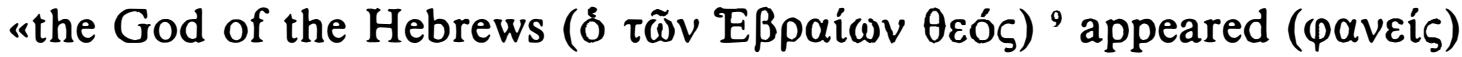
to the prophet $(\tau \tilde{\varphi} \pi \rho \circ \varphi \eta \eta \eta \eta){ }^{10}$ Elijah and bade him...". Several features of this Josephan reformulation call for special comment. First, there is the historian's substitution of the deity himself for the biblical angel. Josephus' handling of the biblical references to angels, i. e. heavenly messengers, has recently been surveyed in some detail by Michael Mach ". What emerges from Mach's discussion is that Josephus deals quite variously with those references, just as, in many cases, it is not easy to discern why he adopts the particular procedure he does. To be noted, first of all, is that in a whole range of contexts Josephus does reproduce the Bible's mention of supernatural "angel(s)", see, e. g., I 219 (= Gen 21,17), BJ V 388 (=2 Kgs $19,35)$. On the other hand, in numerous other instances he uses alternative terminology either in place of or alongside biblical references to angels, designating the figures in question as, e.g., "phan-

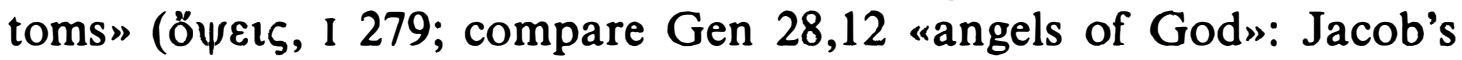
dream at Bethel); "visions" ( $\varphi \alpha \nu \tau \alpha ́ \sigma \mu \alpha \tau \alpha$, I 325; compare Gen 32,1 "angels of God»: Jacob's encounter at Mahanamim); "a spectre in the form of a young man" ( $\varphi \alpha \tau \tau \alpha$ o $\mu \alpha \tau o \zeta . . . v \varepsilon \alpha v i \sigma \tau o v \mu \circ \rho \varphi \tilde{n}, \mathrm{~V}$ 213; compare Judg 6,11-12 "the angel of the Lord»: Gideon's call) and "someone" ( $\tau$ ivos VIII 349, compare 1 Kgs 19,5 "an angel»: Elijah strengthened for his journey to Horeb). Thus, one may speak of a certain "deangelizing" of the biblical record effected by Josephus ${ }^{12}$. For our purposes it is especially interesting to note that, not

${ }^{9}$ This designation for the deity apparently occurs only here in Josephus. On Josephus' denominations for the chosen people at the various points in their history (the Hebrews, the Israelites, the Jews), see A. ARAzY, The Appellations of the Jews (Ioudaios, Hebraios, Israel) in the Literature from Alexander to Justinian, Diss. New York University 1973, pp. 170-181.

${ }^{10}$ Note that in VIII 360 Josephus makes the same substitution of "Elijah the prophet" for the "Elijah the Tishbite" of $1 \mathrm{Kgs} 21,17$. Josephus does, however, make reference to Elijah's place of origin in his intitial presentation of him in VIII 319.

$" \mathrm{M}$. MACH, Entwicklungsstadien des jüdischen Engelglaubens in vorrabbinischer Zeit, Tübingen 1992, pp. 300-332.

${ }_{12}$ Mach (see previous note) relates this tendency, in first place, to Josephus' animosity towards the Zealots who would have set great store in angelic support for their revolt against Rome. 
only in IX 20, but also elsewhere, another such Josephan substitution for the Bible's angel is precisely the deity himself, see, e.g., I $233 \mathrm{ff}$.: "God" addresses Abraham who is about to sacrifice his son (compare Gen 22,15-18 where "the angel of the Lord" does so), and VIII 239: "God" has sent the Bethel prophet to take his Judean colleague to

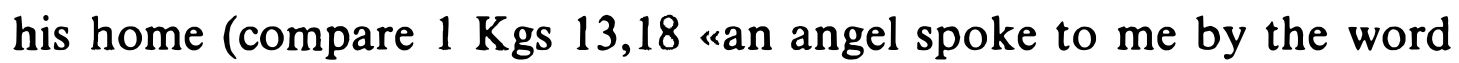
of the Lord..."). Thus, our text is not unique within the Josephan corpus in its attributing to God the speaking initiative the Bible ascribes to an angel. In IX 20, however, God not only speaks to Elijah; he also "shows himself" to him. Here again, Josephus' deviation from the biblical presentation is in line with what one finds elsewhere in his retelling of the Bible's story where, in a whole series of instances, the historian introduces mention of a divine appearance where his source cites only a speaking by God ${ }^{13}$.

2 Kgs 1,3b-4a cites the angel's word to Elijah consisting of commissioning of the prophet (v. $3 b \alpha$ ), accusation against Ahaziah in question form (v. $3 b \beta)$ and announcement of doom for the king (v. 4a) in direct discourse. Josephus, in accord with his frequent practice throughout Antiquities, transposes the whole complex into indirect discourse ${ }^{14}$. Note further that, in formulating the rhetorical question of v. $3 \mathrm{ba}$ : «is it because there is no God in Israel ${ }^{15}$ that you (Ahaziah) are going to inquire of Baalzebub...?", the historian introduces a contrast between the people of Israel's "own god"

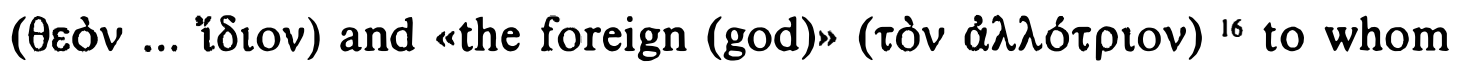
Ahaziah is having recourse. By means of this (re-) formulation, Josephus imparts a more general character to the opposition expressed in the source's question; the Lord as Israel's "own god" is now contrasted, not with one particular deity (Baalzebub), but with

${ }^{13}$ On this feature of Josephus' version - which seems inspired, in part at least, by Greek religion's emphasis on divine epiphanies - see the list of examples and the bibliographical references cited in C. BEGG, Josephus' Account of the Early Divided Monarchy (AJ 8,212-420), Leuven 1993, pp. 53-54, n. 300.

14 On this Josephan tendency, see C. BEGG, Josephus' Account, pp. 12-13, n. 38 and the literature cited there.

15 Thus MT B and TJ. In L 4 Rgns 1,3 the question opens rather «Is it because there is no prophet in Israel...?".

16 Elsewhere Josephus designates the Lord as Israel's "own God" also in Ant. VIII 192.194.290.335.338. The above phrase "foreign god" recurs in Ant. IX 98 and X 68 (both times in the plural). 
any "foreign god" ${ }^{17}$. Finally, in anticipation of 1,6 where the messengers report to Ahaziah that Elijah had enjoined them to "go back to the king ... and say to him", Josephus, already here, has God instruct Elijah to "command them (the messengers) to return and tell the king...".

\section{KING-MESSENGERS EXCHANGE $(1,4 \mathrm{~b}-8)$}

$2 \mathrm{Kgs}$ 1,4b-5a comprises two paratactically linked sentences which effect a -rather abrupt - transition between Elijah's commissioning (1,3-4a) and the conversation between king and messsengers (1,5b8). This reads: "and Elijah went (+ and he spoke to them [Ahaziah's messengers], BL) and the messengers returned to him (Ahaziah)". Josephus (IX 21) creates a smoother transition with the use of a series of participial phrases: "so Elijah did what God commanded [i. e. go to meet the messengers and direct them to return to the king with a word from God for him], and when the messengers heard his words, they at once ${ }^{18}$ returned to the king". In 1,5b Ahaziah's first word to the messengers is a question: "why have you returned?". Such a question might appear odd addressed to messengers who, after all, were expected to return to the one who sent them. Josephus takes care to provide a motivation for Ahaziah's query which, at the same time, picks up on his previously inserted reference to their returning "at once»: "he wondered at the speediness 19 of their return...".

In 1,6 the messengers commence their reply to Ahaziah with mention of a "man" (BL $\alpha v \eta \dot{\eta} \rho)$ who came to «meet» them. Josephus too has the messengers cite their meeting «a certain man $(\& v \theta \rho \omega \pi \circ)$ ». He adds as well a further qualification of Elijah which -like his earlier insertion of "at once», see above- serves to accentuate the prophet's irresistible authority: «he prevented them

17 A similiar generalizing tendency may be seen in Josephus' version of the contest between the Lord and Baal (1 Kings 18,17-40) in VIII 335-343, see n. 8. See also C. BEGG, Josephus' Account, p. 187 and n. 1235.

18 Josephus' insertion of this indication underscores the authority of Elijah's word. It likewise prepares Josephus' - also inserted- notice concerning Ahaziah's immediate reaction to the messengers' return, see above in the text.

19 I use italics to indicate those elements of Josephus' version which have no biblical equivalent as such. 
from going farther». Having mentioned the man's meeting them, the royal messengers in $\mathrm{v} .6 \mathrm{a} \beta \mathrm{b}$ proceed to relate his words to them. These comprise a (re-)commissioning of them as messengers to Ahaziah plus the communication of the message they are to convey. The latter item is introduced with a Botenformel and essentially reproduces the judgment speech with its sequence of rhetorical question-accusation and announcement of punishment of vv. 3b$4{ }^{20}$. Josephus, first of all, shortens the prophetic word as relayed by the messengers, eliminating its accusation element. He likewise varies the language of the initial announcement of punishment: "he would not recover from his illness", and its reiteration here: «... your illness would get worse». Thereby, he avoids the Bible's largely verbatim repetition of the announcement of Ahaziah's fate. Finally, in line with his regular practice, he substitutes an alternative phrase for the source's Botenformel, i. e. «by the command of the God ( $\xi \xi$

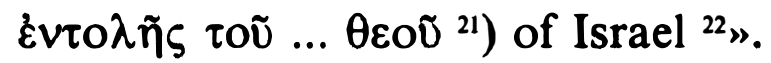

The dialogue between king and messengers continues in 1,7 with

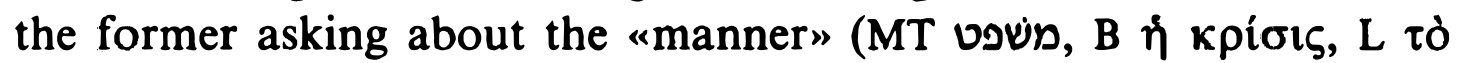
$\delta$ ikai $\omega \mu \alpha)$ of the man they had encountered. Josephus employs equivalent terminology: Ahaziah bids the messengers "describe"

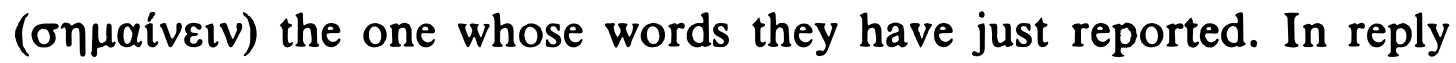
to the king's new question the messengers $(1,8 \mathrm{a})$ supply a two-fold characterization of the unknown figure: he was a "hairy man" (MT

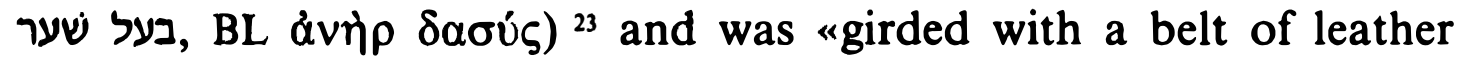

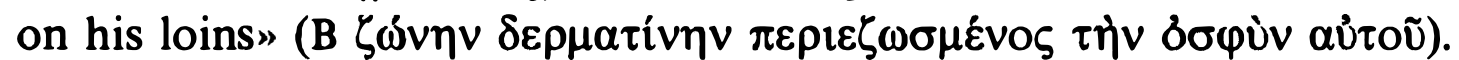
Josephus' version of this double description is quite reminiscent of

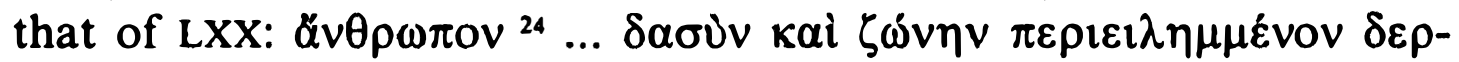
$\mu \alpha \tau i v \eta v$. The king-messengers exchange concludes in $1,8 \mathrm{~b}$ with Ahaziah reacting to the envoys' description with the declaration: «it is

${ }^{20}$ In L 4 Rgns 1,6 there is a long plus following the announcement of Ahaziah's coming demise in which, in language reminiscent of $1 \mathrm{Kgs} 21,21$, etc., Ahaziah is charged with doing evil and so evoking the divine decision to annihilate the house of Ahab. Like MT, TJ and B, Josephus has no equivalent to this plus.

${ }^{21}$ This is Josephus' only use of this precise construction.

${ }^{22}$ Compare "the God of the Hebrews", IX 20. Elsewhere Josephus employs the above expression, literally "God of the Israelites", also in IX 60.

${ }^{23}$ Contrast the RSV rendering of the MT phrase: "he wore a garment of haircloth». On the translation question here, see the commentaries.

${ }^{24}$ Recall that in his version of 1,6 as well Josephus has this term for "man" in place of BL's \&urip. 
Elijah the Tishbite». Josephus, here too, provides a more flowing transition between items that the Bible simply strings together paratac-

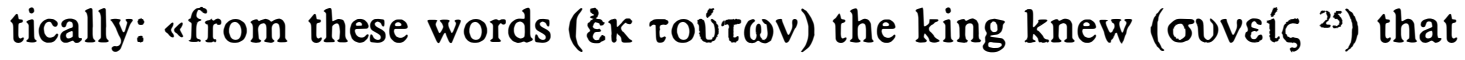
the man... was Elijah ${ }^{26} \ldots$...

\section{AHAZIAH'S TRIPLE MISSION (1,9-14)}

The core of our episode is the account of Ahaziah's dispatch of three groups of soldiers against Elijah, their dealings with the prophet and fate at his hands. In 1,9a the first of these "missions" is paratactically juxtaposed to the king's declaration of $1,8 \mathrm{~b}$ «and he said ... and he sent to him...". Josephus uses participial phrases to fashion a more flowing transition between the two items: "understanding that the man ... was Elijah, sending an officer after him ... he ordered...". The Bible designates those sent by Ahaziah as a "captain of fifty men (MT שר־ח, BL $\pi \varepsilon v \tau \eta \kappa o ́ v \tau \alpha \rho \chi o v)$ and his fifty". Josephus formulates the reference using standard Greek military terminology: «an officer ( $\tau \alpha \xi i \alpha \rho \chi o v{ }^{27}$ ) with fifty [heavily armed] soldiers ( $\delta \pi \lambda i \tau \alpha \varsigma)$ ". To the mention of the force's dispatch by Ahaziah, the historian likewise adds a clarification as to its objective: "he ordered him (Elijah) to be brought (to him)" ${ }^{28}$.

In $1,9 \mathrm{~b}$ the captain ascends ${ }^{29}$ to Elijah who has seated himself "on the top of the hill ${ }^{30}$ " and there speaks with him. In Josephus as well Elijah is said to be sitting "on the top of the hill" ( $\varepsilon \pi i$ iñs

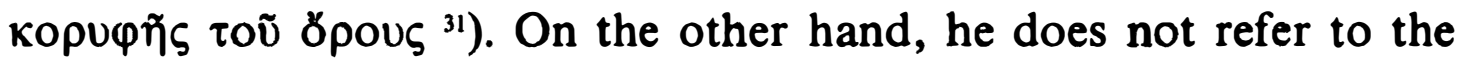
officer "going up" to Elijah. In his version then the commander

${ }^{25}$ With this construction compare Ant. VIII 402 «Josaphat saw by their [i. e. of the 400 prophets of Ahab] words (ovveis $\varepsilon \kappa \tau \tilde{} \tau \nu \lambda \delta \gamma \omega v$ ) that they were false prophets...".

${ }^{26}$ As in his version of 1,3 (see above), Josephus dispenses with the biblical qualification of Elijah as «the Tishbite».

${ }^{27}$ This term is the Greek equivalent of the Latin centurio, see K. H. RENGSTORF (ed.), A Complete Concordance to Flavius Josephus, IV, Leiden 1983, s.v.

${ }^{28}$ Like MT B and TJ, Josephus has no equivalent to the $L$ plus after 1,9a which states that the force did in fact go to Elijah.

${ }^{29}$ In $\mathrm{L}$ his fifty soldiers go up as well.

${ }^{30}$ Commentators generally suggest that the hill being referred to here is Mt. Carmel with which Elijah is associated in 1 Kings 18.

${ }^{31}$ Josephus' phrase here is identical with that of BL 1,9b. Like the Bible, Josephus leaves unnamed the hill on which he has Elijah sit, just as he provides no explanation as to why the prophet had positioned himself precisely at that spot. 
appears to shout up to the prophet on the hill. The lack of respect implicit in such a procedure goes together with the content of his words which in Josephus are considerably more peremptory and threatening than in the Bible. Specifically, the biblical officer first addresses Elijah with the honorable title "man of God" and then continues "the king says, "Come down'». His Josephan counterpart dispenses with any form of address. Conversely, he "orders" Elijah "to come down and go to the king ${ }^{32}$, saying that he had so ordered ${ }^{33}$, and, if he refused, he would force him to go against his will». By thus accentuating the "threat quotient" in the officer's address, Josephus, at the same time, makes Elijah's violent reaction (see below) seem better motivated than in the source where it seems out of all proportion to the captain's actual offense.

Elijah's initial response in 1,10 picks up on the officer's addressing him as man of God; it begins «if I am a man of God...". As noted above Josephus' commander dispenses with any title or address for Elijah. In reporting in indirect discourse the protasis of Elijah's reply, he once again avoids the biblical title, rendering rather «... to prove $(\varepsilon \pi i \pi \varepsilon i \rho q)$ whether he was a true prophet ( $\pi \rho \circ \varphi \eta i n s ~ d i \lambda$ $\eta \theta \dot{\eta} \varsigma{ }^{34}{ }^{31}$. With this substitution, Josephus goes together with TJ which words the opening of 1:10 «if I am a prophet of the Lord...". That substitution is, moreover, one made consistently by both Josephus and TJ, both preferring the more precise "prophet" to the indeterminate designation "man of God" ${ }^{35}$. The apodosis to the biblical Elijah's reply constitutes a kind of curse: «... let fire come

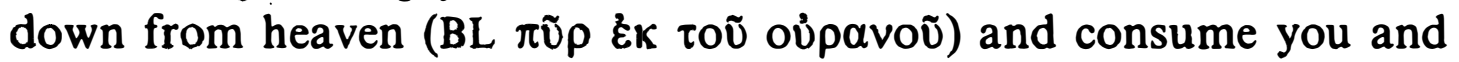
your fifty". Josephus prefaces this part of the prophet's reply with the statement $4 . .$. he would pray for $\left(\varepsilon \delta \varepsilon^{\xi} \varepsilon \sigma \theta \alpha \imath\right) »$, and then continues «fire to fall from heaven ( $\pi \tilde{u} \rho \alpha \pi^{\circ}$ oúpavoṽ $\pi \varepsilon \sigma \delta \delta$ ) and destroy

${ }^{32}$ Recall Josephus' inserted specification concerning the reason for Ahaziah's sending his force to Elijah: "he ordered that he be brought to him".

${ }^{33}$ Note the double use of the term "order" ( $\left.\kappa \varepsilon \lambda \varepsilon \cup ́ \omega\right)$ in Josephus' report of the officer's word to Elijah; this too serves to underscore the high-handedness with which the former deals with the prophet.

34 Elsewhere Josephus uses the expression "true prophet" in Ant. VI 47 (Samuel) and VIII 296 (of the figure Israel will lack in the future should it turn apostate), cf. IX 34 where it is employed ironically by Elisha in reference to the prophets of Ahab and Jezebel. With Elijah's above call for a test of his status as true prophet, compare VIII 408 where Zedekiah says to Ahab concerning Micaiah «... you shall know [i. e. by the outcome of my striking him] whether he is really a true ( $\alpha \lambda \eta \theta \dot{\eta} \varsigma)$ (prophet)...".

${ }^{35}$ See further C. BEGG, Josephus' Account, pp. 32-33, n. 129, p. 44, n. 213. 
( $(\dot{\pi} \mathrm{\alpha} \lambda \dot{\varepsilon} \sigma \alpha \varsigma)$ both his soldiers and himself". With his inserted reference to Elijah's praying for the heavenly fire, Josephus makes clear that the prophet does not have this celestial power at his own disposition; he can only request, not command, it to perform. In addition, that amplification serves to accentuate the parallelism between our episode and a previous incident involving Elijah and "heavenly fire", i. e. the Carmel contest, see VIII 342 (= 1 Kgs 18,36-37) where having prepared his sacrifice, Elijah «began to pray ( $\varepsilon$ u้ $\chi \varepsilon \sigma \theta \alpha$ ) $)$ to God and entreat him" with the result that "fire fell from heaven" ( $\pi \tilde{0} \rho \dot{\varepsilon} \xi$

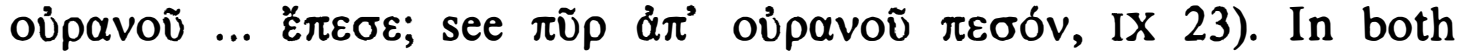
cases, Josephus has no magical control over the heavenly fire; he must pray God to send it. 1,10b describes the realization of Elijah's curse utilizing the same language as the curse itself: "and fire came down from heaven and consumed him and his fifty" (see above). After noting that in fact Elijah did pray, Josephus describes the outcome in wording somewhat varied from that of the prayer itself:

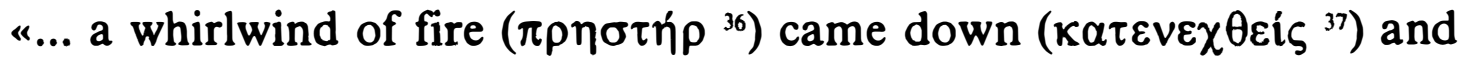
consumed both the officer and those with him".

In 1,11a Ahaziah's second mission is rather abruptly juxtaposed with the disastrous conclusion to the first: "again the king sent to him another captain of fifty men with his fifty». Josephus fills in the blanks here with his interjected transitional phrase: "when the destruction $\left(\alpha \pi \omega \lambda \varepsilon i \alpha \varsigma^{38}\right)$ of these men was reported to the king, he became very angry ( $\pi \alpha \rho \circ \xi u v \theta \varepsilon i \zeta){ }^{39}$ and sends $\left(\pi \varepsilon \mu \pi \varepsilon l{ }^{40}\right) \ldots " .2 \mathrm{Kgs}$ $1,11 \mathrm{~b}$ recounts the initiative of the second captain in language largely similar to that of v. 9b: he too "goes up" ${ }^{41}$ to Elijah to whom he conveys the royal directive that he is to "come down". This time, however, that directive is formulated in somewhat more

${ }^{36}$ This term is hapax in Josephus.

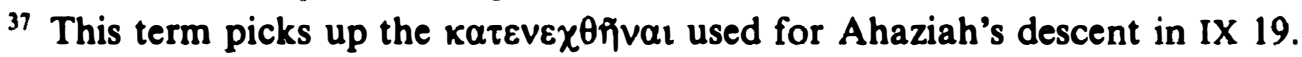

${ }^{38}$ This term picks up the verb \& $\pi 0 \lambda \varepsilon \sigma a l$ in Elijah's prayer in IX 23.

39 This inserted reference to the king's emotional state is an example of Josephus' tendency to psychologize the biblical account by introducing references to the feelings of characters. In particular, in a whole series of cases, Josephus uses the above participle in citing the rage which some experience evokes from a character, see C. BEGG, Josephus' Account, pp. 46-47, n. 234.

40 Josephus uses the historic present with considerable frequency throughout his writings, doing so under the influence both of the LXX and of such Hellenistic historians as Dionysius of Halicarnassus and Nicolas of Damascus, see C. BEGG, Josephus' Account, pp. 10-11, n. 32.

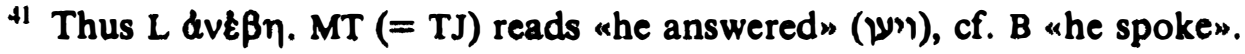


emphatic terms: the simple "the king says" of 1,9 now becomes a Botenformel "thus says the king", just as Elijah is enjoined to descend "quickly". As with the first officer, Josephus here makes no mention of his colleague's ascending to Elijah or addressing him by title. At the same time, he does accentuate the threatening character of the second commander's words: "this one also threatened the prophet that he would seize him by force and take him away if he did not come down willingly (ßouגó $\mu \varepsilon v o \zeta)$ ». Thus, in his own way, Josephus too indicates a progression in the peremptoriness with which Elijah is told to descend from the first to the second exchange.

$2 \mathrm{Kgs}$ 1,12 repeats 1,10 virtually verbatim: Elijah calls for heavenly fire which falls and annihilates the second force. This time, Josephus refrains from reporting the actual words of the prophet's response to his summoner; rather he simply notes that Elijah "prayed ( $\varepsilon \cup 3 \xi \alpha \mu \varepsilon$ vov; see $\varepsilon \cup 0 \chi \varepsilon \tau \alpha$, IX 23) against him" with the result that

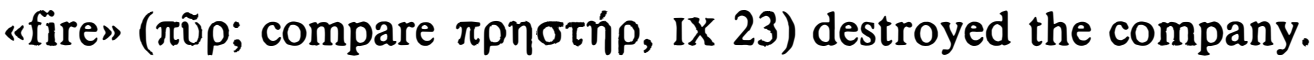

In $1,13 a$ the third royal mission is once again simply juxtaposed paratactically to the preceding notice on the annihilation of the previous force. Here too, Josephus introduces a transitional mention of Ahaziah's "learning of" the latter event. Vv. 13b-14 portray the third captain as displaying a very different demeanor in his dealings with Elijah than had his two predecessors: he kneels before the prophet and pleads for his life and that of his men. Josephus sets up this shift with the double characterization of the third captain with which he prefaces the report of his exchange with Elijah: «being a prudent man $\left(\varphi \rho \delta ́ v \imath \mu \circ \varsigma^{42}\right)$ and of a very mild ( $\left(\varepsilon \pi \imath \varepsilon \iota \kappa \eta \varsigma^{43}\right)$ disposition..." ${ }^{44}$. In the same line he qualifies the officer's speaking to Elijah as «friendly» $(\varphi \imath \lambda \circ \theta \rho o ́ v \omega \varsigma){ }^{45}$.

${ }^{42}$ Josephus uses the above adjective a total of $8 x$. On the term and its cognates in Josephus, see G. BERTRAM, "Фpทं $v \tau \tau$.", in TWNT 9 (1973) 216-231, 224-225.

${ }^{43}$ This adjective occurs $28 \mathrm{x}$ in Josephus. Only here is it collocated with the word

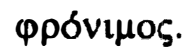

${ }^{44}$ Such inserted characterizations which provide readers with advance perspective on what to expect of a given figure and how they are to regard that figure are a regular feature of Josephus' rewriting of the biblical record, see, e.g., Ant. VIII 236 where, prior to reporting the intiatives taken by the Bethel prophet with regard to

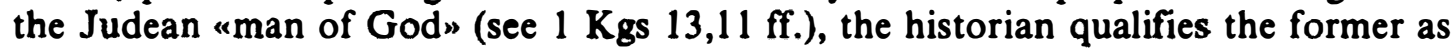
"a wicked old man, a false prophet».

${ }^{45}$ As in the case of his two colleagues, Josephus does not take over the biblical indication that the third officer "went up" to Elijah. Accordingly, he likewise leaves 
The discourse which the third captain addresses to Elijah comprises a double appeal that his life and that of his fellows «be precious in the eyes of" Elijah (vv. 13b $\beta, 14 \mathrm{~b}$ ) with a reference to the fate of the two previous groups intervening (v. 14a). In this formulation, what it is the captain wants of Elijah remains rather indeterminate, just as it is not immediately clear how his evocation of his colleagues' end is supposed to relate to the appeal he makes. Josephus clarifies matters in his version of the third officer's speech. This begins with the commander's citing a reason why Elijah should pay heed to his following appeal, i. e. the fact that both he and his

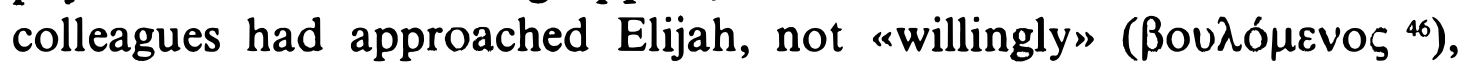
but under royal compulsion ${ }^{47}$. Having thus presented himself and his colleagues as the king's reluctant agents, the captain next proceeds to formulate a two-fold, appeal. First, in a clarification of the biblical phrase about his and his men's lives being «precious in the eyes of" Elijah, he asks the prophet "to have pity ( $\dot{\varepsilon} \lambda \varepsilon \tilde{\eta} \sigma \alpha \imath)$ on him and on the soldiers who were with him». Secondly, he requests, without a basis in the words attributed to the captain in $1,13 \mathrm{~b}-14$ as such (although see the continuation of the story), that he "come down and accompany him to the king".

$2 \mathrm{Kgs} 1,15 \mathrm{a}$ rounds off the exchange between prophet and third officer with mention of a new (see 1,3) intervention by an "angel of the Lord" who instructs Elijah to descend with his interlocutor whom he is "not to fear". As will be recalled, Josephus' version of 1,3 (see IX 20) replaces its reference to the angel with an appearance by God himself to Elijah. Here in IX 26, Josephus goes a step further in his reworking of the Bible's reference to an angel. As the historian presents things, Elijah makes his response to the officer's appeal without any kind of supernatural guidance, angelic or divine,

aside 1,13's mention of his kneeling before the prophet. Like the Bible, Josephus leaves the third captain nameless. In the Lives of the Prophets 9.3 (first cent. A.D.?) he is identified with the future prophet Obadiah.

46 This participle picks up the term used (IX 24) by the second officer who threatens to take Elijah by force if he will not come "willingly". As it now turns out, all three officers as well as Elijah himself are united in their unwillingness to do as directed by the king.

47 The third commander's assertion about his two colleagues here comes as a surprise since nothing in Josephus' previous depiction of their exchanges with Elijah suggests any reluctance on their part to carry out the royal mandate. In any case, the reference to them represents Josephus' version of the captain's allusion to their fate as cited in $1,14 \mathrm{a}$. 
but solely on the basis of the impression made on him by latter's speech: "so Elijah, approving of the tactfulness $\left(\delta \varepsilon \xi\right.$ ló $\left.\tau \eta \tau \alpha{ }^{48}\right)$ of his words and the courtesy ( $\left.\dot{\alpha} \sigma \tau \varepsilon \tilde{i} o{ }^{49}\right)$ of his manner ${ }^{50}$, came down...". Why does Josephus proceed as he does here? I suggest that he may have concluded that a supernatural directive to the prophet was really not called for at this juncture. After all, Elijah had dealt with the first two captains entirely at his own discretion - why could he not do so with the third as well? In addition, the biblical angel's actual injunction that Elijah "not fear" the last officer appears somewhat strange; Elijah who had shown no fear in the face of the first two commanders' peremptory summons certainly had no reason to be afraid of their suppliant colleague. In view of these considerations, Josephus, I propose, opted not to tax the credulity of his sophisticated Gentile audience with a second recourse to a deus ex machina in a single story. What he offers them in its stead is an illustration of the efficacy of tactful speech, a lesson that audience would surely have found more congenial ${ }^{\mathrm{s1}}$.

ELIJAH BEFORE THE KING $(1,15 b-17 a)$

Our episode concludes with Elijah coming before the king (v. $15 b)$ to whom he delivers his word of doom (v. 16) whereupon Ahaziah dies (v. 17a). In v. 16 the angel's initial announcement to Elijah is repeated by him largely verbatim for the third time in the story (see vv. 3 and 6b). Here again, Josephus' version evidences a concern with avoiding the source's verbal repetitions. The variation introduced by him begins already with the opening formula of Elijah's address to the king. In 1,16 this is the standard Botenformel. Josephus previously (see IX 21) substituted the phrase "at the command of the God of Israel" for the "thus says the Lord" of 1,6.

48 Josephus uses $\delta \varepsilon \xi \xi$ ıó $\eta ऽ \varsigma$ also in Ant. II 41, XVIII 207 and XIX 88.

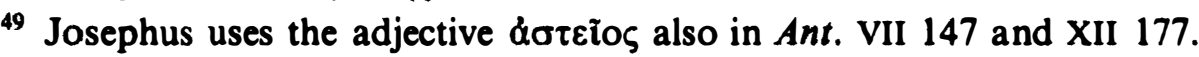

so The above reference to the captain's tactful words and courteous manner recall Josephus' opening characterization of him as «a prudent man and of a very mild disposition" (IX 25).

51 Also elsewhere Josephus eliminates biblical references to the supernatural impetus behind characters' initiatives, see, e.g., Ant. VIII 319 where, in contrast to the source's reference $(1 \mathrm{Kgs} \mathrm{17,2)}$ to "the word of the Lord" that prompts Elijah to retire to the brook, the prophet acts on his own volition. 
Here, he makes a comparable substitution, indicating the supernatural origin of Elijah's words with the expression "he prophesied

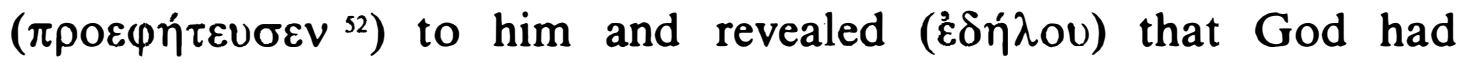
said...». In next citing the content of God's word for Ahaziah, Josephus, exceptionally in our passage, retains the direct discourse of the source, rather than transposing this into indirect discourse. In the judgment speech of 1,16 , the accusation element comprises a charge about Ahaziah's consulting Baalzebub to which is attached (so MT, > BL) a rhetorical question about there being no God in Israel ${ }^{53}$. Josephus reformulates the biblical rhetorical question into a direct charge against the king: «because you have scorned him

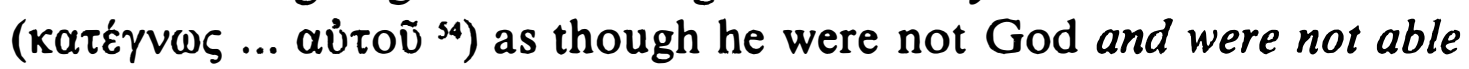
to foretell the truth ( $\tau \dot{\alpha} \lambda \eta \theta \dot{\varepsilon} \varsigma \pi \rho \circ \varepsilon \imath \pi \varepsilon \tilde{\imath}{ }^{s 5}$ ) concerning your illness". Reversing the biblical sequence, he has Elijah then continue: «but

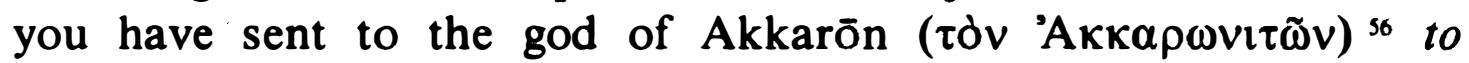
inquire of him what the end of this illness will be» ${ }^{57}$. Thereafter, he reproduces the death announcement from the end of v. 16, passing over (as previously in his version of vv. 3 and 6) the preceding statement that Ahaziah «will not come down from the bed to which he had gone up" as superfluous.

2 Kgs 1,17a narrates Ahaziah's death in accordance with the Lord's word as spoken by Elijah. Josephus (IX 27) begins his parallel notice with the indication that Ahaziah's demise took place "a very short time thereafter» ${ }^{58}$. As is his wont, Josephus likewise

52 This verb occurs a total of $58 \mathrm{x}$ in Josephus (only once in BJ, i. e. 1 69).

${ }^{53}$ Note that in the previous formulations of the accusation in vv. 3 and 6 , these two elements stand in reverse order.

54 Only here does Josephus use the above construction $\kappa \alpha \tau \alpha \gamma i v \omega \sigma \kappa \omega$ (= scorn) with God as genitival object.

ss Elsewhere Josephus employs the above expression "foretell truly" of the Egyptian sacred scribe whose predictions about the future achievements of Moses did come about in Ant. II 209.

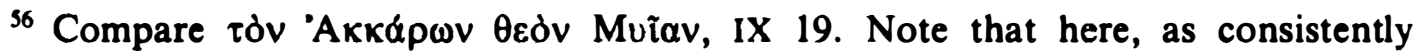
throughout our episode, Josephus avoids the biblical designation "Baalzebub".

57 This specification about the purpose of Ahaziah's sending to the god of Ekron has no parallel in 1,16. Compare Josephus' previous wordings on the matter: "to inquire about his chances of recovery" (IX 19) and "to ask about his chances of recovery" (IX 20).

58 Compare IX 21 where Josephus inserts the specification that upon encountering Elijah the messengers at once returned to Ahaziah. In both instances, the effect of Josephus' interjected time indications is to underscore the irresistible authority of the prophet's word. 
employs alternative terminology for the source's mention of the divine word, stating that Ahaziah died «as Elijah had foretold

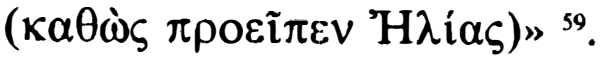

\section{CONCLusion}

By way of conclusion to my study of Josephus' version of Ahaziah's fall in relation to the biblical source(s), I shall now sum up my findings under two headings, i. e. the text(s) of 2 Kings 1 used by him and the rewriting techniques he employs in retelling the story. On the textual question, the evidence does not seem to allow any assured positive conclusion as to whether Josephus used 2 Kings 1 in its (proto-) MT or LXX form. Negatively, however, it is of interest to note, given the widespread scholarly view that Josephus' primary text for the Historical Books from 1 Samuel on was a proto-Lucianic one, that in our passage the historian lacks an equivalent to the $L$ plusses in vv. 2,3,6, and 9. At least in the case of 2 Kings 1 then, that long-standing consensus seems open to question.

More can be said on the characteristic rewriting techniques evidenced by our segment of Antiquities. On the stylistic level, we have noted Josephus' tendency to replace verbal repetition with varied formulations, direct with indirect discourse, parataxis with hypotaxis, as well as his use of the historic present. The historian's version likewise reveals something of his terminological preferences as compared with the biblical ones: the source's messenger formulas, mention of the "divine word" and designation "man of God" are all avoided in favor of alternative phraseology. As far as content goes, Josephus reproduces the matter of 2 Kings 1 without large-scale omissions or re- arrangements of its sequence. On the other hand, he does take the liberty of introducing a variety of smaller additions which serve to improve the flow of the story and/or to prepare what will follow, e. g., Ahaziah's wonderment at the messengers' speedy return (IX 21), his being informed of the fate of his two earlier missions and his anger over the first of these (IX 24,25), and the initial characterization of the third captain (IX 25). Josephus also modifies the data of the source story in several respects. The

${ }^{59}$ On Josephus' general tendency to replace biblical mentions of the divine word with alternative phraseology, see C. BEGG, Josephus' Account, p. 20, n. 90. 
threatening character of the first two captains' words to Elijah is accentuated, this providing something more of a justification for their subsequent annihilation, while the prophet's curse upon them becomes a prayer (see IX 23,24). Most noteworthy in this regard is Josephus' handling of the double angelic intervention of $2 \mathrm{Kgs} \mathrm{1:3}$ and 15. As will be recalled, Josephus replaces the first of these with a divine appearance (see IX 20), while in the second case Elijah is portrayed as acting entirely on his own initiative without any kind of supernatural direction. Thus, the angel of the Lord who is a major player in the biblical account completely disappears in Josephus' retelling. For the rest, I would note that Josephus refrains from explaining or elaborating on items in the source narrative that might well seem to call for this. Like the Bible, e. g., he gives no name to the mountain on which Elijah takes his seat, just as he says nothing as to the circumstances of the prophet's positioning himself there (see IX 23, 2 Kgs 1,9). Again, the Josephan Ahaziah too makes no response when Elijah whom he has so assiduously pursued finally appears before him with his word of doom (see IX 26, 2 Kgs 1,16). Also worthy of note is the fact that Josephus appears to have felt no need to add any kind of commentary on the Bible's story of Elijah's two acts of (disproportionate) violence -in fact, Josephus might seem to accentuate the problem by having the third captain affirm that his colleagues had come out against Elijah "unwillingly" (see IX 25) ${ }^{60}$.

In sum Josephus' account of Ahaziah's fall stands as a generally faithful, straightforward retelling of the biblical story which, however, is not without a variety of interesting peculiarities.

${ }^{60}$ On Josephus' overall treatment of Elijah, see L. H. FELDMAN, «Josephus' Portrait of Elijah", SJOT 8 (1994) 61-86. 


\section{RESUMEN}

2 Re 1,2-17a relata las dramáticas circunstancias que rodearon la muerte del rey de Israel Ocozías, tras un reinado de sólo dos años. Este artículo analiza la versión de Josefo (Ant. IX 19-27) de la fuente bíblica. Su estudio muestra los diversos retoques estilísticos, terminológicos y de contenido introducidos por el historiador en su narración y ofrece algunas sugerencias sobre las razones y los efectos de esos cambios. El tratamiento que da Josefo a la doble intervención angélica del texto fuente $(2 \operatorname{Re} 1,3.15)$ recibe una atención especial.

\section{SUMMARY}

$2 \mathrm{Kgs}$ 1,2-17a relates the dramatic circumstances surrounding the death of king Ahaziah of Israel after a reign of only two years. This article examines the Josephan version of the episode (Ant. IX 19-27) in relation to the biblical source. The study notes the various sorts of stylistic, terminological and content retouchings introduced by the historian in his re-telling of the incident, and offers suggestions about the reasons and effects of these changes. The historian's treatment of the double angelic intervention of the source text $(2 \mathrm{Kgs} 1,3.5)$ receives special attention. 